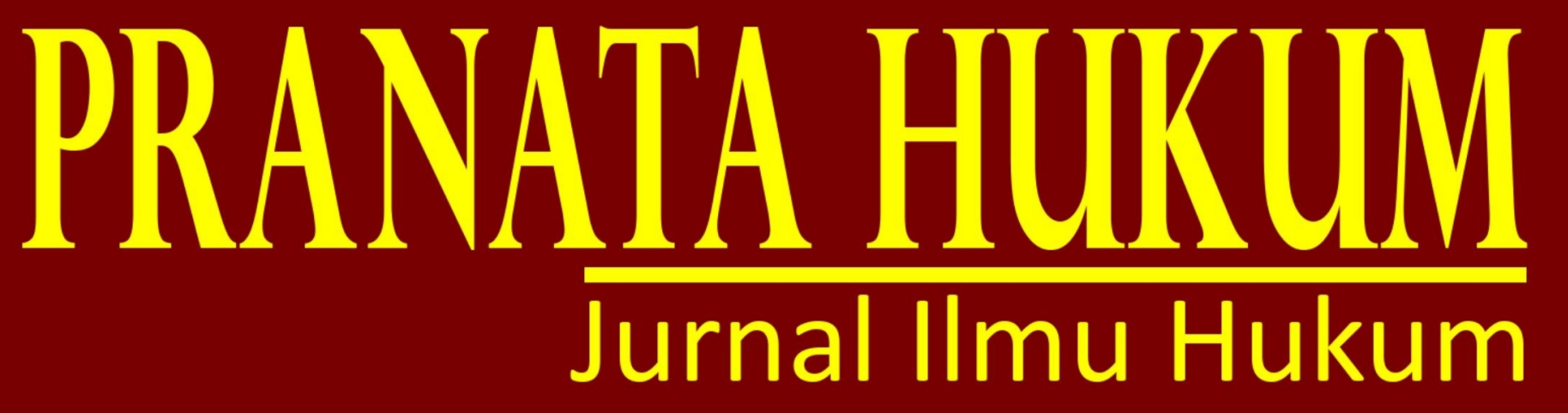

e-ISSN 2685-3213 | p-ISSN 1907-560X

EFEKTIVITAS ASEAN CONVENTION ON COUNTER TERRORISM DI DALAM MEMBERANTAS PEMBAJAKAN DI WILAYAH PERAIRAN ASIA TENGGARA

Rafi Darajati, Muhammad Syafei

PERLINDUNGAN HUKUM PENGGUNA JALAN DARI ANGKUTAN UMUM ONLINE PADA PENGGUNAAN TELEPON SAAT MENGEMUDI KENDARAAN

Rissa Afni Martinouva

ANALISIS PERTANGGUNGJAWABAN PELAKU TINDAK PIDANA MELAKUKAN PENEBANGAN POHON DALAM KAWASAN HUTAN TANPA IJIN YANG BERWENANG

Sukoco SP, Erlina B , Eddy S Wirabhumi

PERLINDUNGAN HUKUM PASIEN PADA BIDAN PRAKTIK MANDIRI DI INDONESIA PASCA DIKELUARKANNYA UNDANG-UNDANG NOMOR 4 TAHUN 2019 TENTANG KEBIDANAN Aditia Arief Firmanto

FUNGSI PENGAWASAN PERADILAN TATA USAHA NEGARA TERHADAP PERBUATAN PEMERINTAH PASCA UNDANG-UNDANG NOMOR 30 TAHUN 2014 TENTANG ADMINISTRASI PEMERINTAHAN Muhammad Rusjana

PELAKSANAAN PENGADAAN BARANG/JASA PEMERINTAH DITINJAU DARI PERPRES NOMOR 16 TAHUN 2018 TENTANG PENGADAAN BARANG/JASA PEMERINTAH DI KANTOR PERTANAHAN KOTA BANDAR LAMPUNG Aryana Wisastra, Baharudin, Indah Satria

KEWAJIBAN TANGGUNG JAWAB SOSIAL PERUSAHAAN (CORPORATE SOCIAL RESPONSIBILITY) DI INDONESIA: ANTARA LEGAL OBLIGATION ATAU MORAL OBLIGATION

Dani Amran Hakim, Dania Hellin Amrina

IMPLEMENTASI PERATURAN MENTERI AGRARIA DAN TATA RUANG/KEPALA BADAN PERTANAHAN NASIONAL NOMOR 13 TAHUN 2017 TENTANG TATA CARA BLOKIR DAN SITA PADA KANTOR PERTANAHAN KOTA BANDAR LAMPUNG

Sholin Erbin M Rajagukguk, Lintje Anna Marpaung, Herlina Ratna Sumbawa Ningrum

PEMBERIAN PATEN OBAT-OBATAN DAN PEMENUHAN HAK ASASI MANUSIA TERHADAP KESEHATAN DI INDONESIA

Chandra Muliawan

\begin{tabular}{c|c|c|c|c|}
\hline $\begin{array}{c}\text { PRANATA } \\
\text { HUKUM }\end{array}$ & $\begin{array}{c}\text { Volume } \\
14\end{array}$ & $\begin{array}{c}\text { Nomor } \\
\mathbf{2}\end{array}$ & $\begin{array}{c}\text { Halaman } \\
96-222\end{array}$ & $\begin{array}{l}\text { Bandar } \\
\text { Lampung } \\
\text { Juli 2019 }\end{array}$ \\
\hline
\end{tabular}




\section{PRANATA HUKUM}

Jurnal Ilmu Hukum

Magister Hukum

Universitas Bandar Lampung

Terbit Pertama Kali, Juli 2006

Terbit Dua Kali Setahun, Setiap Januari dan Juli

PENANGGUNG JAWAB

Rektor Universitas Bandar Lampung

KETUA PENYUNTING

Prof. Dr. Lintje Anna Marpaung, S.H., M.H

WAKIL KETUA PENYUNTING

Dr. Bambang Hartono, S.H., M.Hum

PENYUNTING PELAKSANA

Dr. Tami Rusli, S.H., M.Hum

Dr. Erlina B, S.H., M.H

Dr. Zainab Ompu Jainah, S.H., M.H

Indah Satria, S.H., M.H

Yulia Hesti, S.H., MH

\section{PENYUNTING AHLI (MITRA BESTARI)}

Prof. Dr. I Gusti Ayu Ketut Rachmi Handayani, S.H., M.M (Universitas Sebelas Maret) Prof. Dr. I Gede A.B Wiranata, S.H., M.H (Universitas Lampung)

Dr. Nurhadiantomo, S.H., M.Hum (Universitas Muhammdiyah Surakarta)

Dr. Erina Pane, S.H., M.H (UIN Lampung)

Alamat:

Kampus B Universitas Bandar Lampung

Jl. Z.A Pagar Alam No.89 Labuhan Ratu, Bandar Lampung 35142

Telp: 0721-789825 Fax: 0721-770261

Email: jurnal.mh@ubl.ac.id

Jurnal PRANATA HUKUM dimaksudkan sebagai media komunikasi ,edukasi dan informasi ilmiah bidang ilmu hukum. Sajian dan kemasan diupayakan komunikatif melalui bahasa ilmiah.

Redaksi mengundang semua elemen masyarakat ,baik civitas akademika, praktisi , lembaga masyarakat ,maupun perorangan yang berminat terhadap bidang hukum untuk berpartisipasi mengembangkan gagasan, wawasan, dan pengetahuan melalui tulisan untuk dimuat dalam jurnal ini. Melalui PRANATA HUKUM diharapkan terjadi proses pengembangan bidang hukum sebagai bagian penting dari rangkaian panjang proses memajukan masyarakat bangsa 


\title{
PEMBERIAN PATEN OBAT-OBATAN DAN PEMENUHAN HAK ASASI MANUSIA TERHADAP KESEHATAN DI INDONESIA \\ Chandra Muliawan'
}

\begin{abstract}
Patent which one part of the IPR, are legal protection for inventor of an invention both process and product in the field of technology that can be applied in industry. Granting of patents in the pharmaceutical field impact on the high price of the medicines, it affects of public to access health right which a part of human rights. Based on it, the government should be protecting business interests (private) coincide with the protection, respect and fulfillment of the interests of public health (public health). The problem approach in this study normatively by using secondary data is used as supporting data. The requirements and procedure for patent applications are found in Article 24 paragraph (1) of the Patent Law including those granted based on the application. Procedures and descriptions of registered patents are also regulated as fulfilling prior priority rights for inventors who register their inventions. Priority rights also apply to foreigners who are members of the Paris Convention provided for in Article 1 number 12 of the Patent Law. Article 36 paragraphs (1) and (2) of the Health Law state that the Government has an obligation to guarantee the availability, equity and affordability of health supplies, especially essential medicines. Medicine is part of the needs of the wider community which is also an obligation of the Government to fulfill the right to health as part of human rights.
\end{abstract}

\section{Keywords: Human Rights, Pharmaceuticals Patents, Health.}

\section{PENDAHULUAN}

Paten sebagai bagian dari Hak Milik Perindustrian (Industrial Property Right) diberikan untuk semua penemuan, baik dalam bentuk produk atau proses, dalam semua bidang teknologi, sepanjang penemuan yang bersangkutan baru, melibatkan langkah inventif dan dapat diterapkan dalam industry. (Persetujuan TRIPs, Pasal 27). Paten yang merupakan salah satu bentuk monopoli yang diberikan kepada penemu (inventor)atas suatu penemuannya sangat jelas bahwa hak ini bersifat individual. Hal ini senada dengan apa yang dikemukakan oleh Wahyu Sasongko bahwa, konsep kepemilikan (ownership) pada Rezim HKI, lazimnya didasarkan pada hak individual yang diakui sejak dulu, seperti hak cipta, hak paten dan merek, sehingga dapat dikatakan sebagai konsepsi yang bersifat konvensional.( Wahyu Sasongko, 2012: 41).

${ }^{1}$ Dosen Fakultas Hukum Universitas Malahayati, chandramuliawan@gmail.com 
Eksploitasi hasil penemuan baru dari inventor secara ekonomis, merupakan suatu insentif yang adil dan wajar untuk kegiatan penelitian dan pengembangan agar memungkinkan pengembangan teknologi yang cepat. (Muhamad Djumhana, 2014: 164). Tetapi disisi lain, seperti yang dikemukakan Alexandra Indriyanti Dewi, ternyata ada itikad yang tidak murni di dalam setiap penciptaan yang dilandasi aspek hukum Hak cipta dan Kekayaan Intelektual ini. (Alexandra Indriyanti Dewi, 2008: 42). Itikad yang tidak murni itu adalah keuntungan material. Pemegang paten dapat melaksanakan temuannya baik secara sendiri maupun dengan memberikan persetujuan atau ijin atau lisensi kepada orang lain, yaitu: membuat, menjual, menyewakan, menyerahkan, memakai, menyediakan, untuk dijual atau disewakan atau diserahkan hasil produksi yang diberi paten. (http://www.hakpaten.net/hak-paten-pengertian-hak-paten/, diakses pada 11 Maret 2019)

Pemberian Paten dimungkinkan dalam hal sesuatu invensi di bidang teknologi kesehatan, termasuk obat-obatan. Perlindungan memang diperlukan guna menjamin keadilan bagi inventor yang telah berkarya dan menghasilkan penemuan yang bermanfaat khususnya dalam bidang farmasi, yaitu obat-obatan. Tetapi, terhadap bentuk monopoli yang diberikan tersebut membawa ekses terhadap harga obat menjadi mahal dan tidak terjangkau oleh semua golongan masyarakat.

Survei yang dilakukan oleh Health Action International tentang harga obat Amoxicillan Amoxil produksi Smithkline Beecham .(http://en.wikipedia. org/wiki/Beecham Group, diakses kembali pada Tanggal 19 Juni 2019). menghasilkan data bahwa di Pakistan dijual dengan harga 8 dollar AS, Malaysia 34 dollar, di Indonesia 40 dollar, Italia 22 dollar, Selandia Baru 16 dollar, Filipina 29 dollar, Kanada 14 dollar, Jerman 60 dollar dan AS dengan harga 36 dollar AS. Hal ini sebagai salah satu efek dari pemberlakuan ketentuan TRIPs di Indonesia.

Tingginya harga obat akibat adanya Hak ekslusif yang diberikan berupa Paten, berdampak juga pada tidak tersedianya obat bagi seluruh golongan ekonomi masyarakat Indonesia. Nilai-nilai liberal (individualisme) dalam Undangundang HKI, dalam hal ini Paten, melupakan nilai-nilai Pancasila dan tujuan pembangunan nasional sesuai dengan amanat UUD 1945. Maka tidak mengherankan manakala pasal-pasal dalam undang-undang lebih mementingkan kepentingan individu (pemilik dan pemegang HKI) daripada kepentingan masyarakat dan negara.(Candra Irawan, 2011: 145).Pandangan hidup dan kepribadian bangsa Indonesia sebagai kristalisasi nilai-nilai luhur bangsa Indonesia, menempatkan manusia pada keluhuran harkat dan martabat makhluk Tuhan Yang Maha Esa dengan kedasaran mengemban kodratnya sebagai makhluk pribadi dan juga makhluk sosial, sebagaimana tertuang dalam Pembukaan UUD 1945, haruslah secara konsisten dipahami serta dilaksanakan dalam seluruh aspek kehidupan masyarakat. (Bahder Johan Nasution, 2011: 184) 
Idealnya memang terdapat keadilan terhadap pengakuan, penghargaan serta jaminan terhadap suatu karya dari inventor atas invensinya, tidak terlepas juga mengenai paten atas obat-obatan. Tetapi berbicara mengenai pemberian Paten terhadap obat-obatan ini berkaitan erat dengan penjaminan negara terhadap tiga lapisan HAM, yaitu Penghormatan (to respect), Perlindungan (to protect) dan pemenuhan (to fullfil) atas Hak Kesehatan. Pada titik ini lah peran Pemerintah dalam hal penyeimbangan kepentingan Privat (Private Interest) dan kepentingan Publik (Public Interest) terhadap pemenuhan atas hak kesehatan masyarakat.

Hak Kesehatan dalam segala bentuknya dan semua levelnya mengandung elemen yang penting dan terkait. Penerapan yang tepat akan sangat bergantung pada kondisi-kondisi tertentu dalam Negara tertentu. Pelaksanaan fungsi kesehatan publik dan fasilitas pelayanan kesehatan, barang dan jasa-jasa kesehatan, juga program-program, harus tersedia dalam kuantitas yang cukup disuatu Negara. Kecukupan akan Fasilitas barang dan jasa bervariasi dan bergantung pada banyak faktor, termasuk tingkat pembangunan Negara

Hak asasi manusia atas kesehatan diakui dalam perangkat-perangkat internasional. Deklarasi Universal Hak Asasi Manusia menyatakan:

"Setiap manusia mempunyai hak atas standar kehidupan yang cukup, bagi kesehatan dirinya sendiri dan keluarganya, yang mencakup makanan, tempat tinggal, pakaian dan pelayanan kesehatan serta pelayanan sosial yang penting".(Pasal 25 ayat (1) Deklarasi Universal Hak-Hak Asasi Manusia, 1948)

Jaminan hak atas kesehatan juga terdapat dalam Pasal 12 ayat (1) Konvensi Internasional tentang Hak Ekonomi, Sosial dan Budaya yang ditetapkan oleh Majelis Umum Perserikatan Bangsa-Bangsa (PBB) 2200 A (XXI) tanggal 16 Desember 1966, yaitu bahwa negara peserta konvenan tersebut mengakui hak setiap orang untuk menikmati standar tertinggi yang dapat dicapai dalam hal kesehatan fisik dan mental. Indonesia telah meratifikasi beberapa Konvenan Internasional yang mengatur mengenai HAM, termasuk di dalamnya Hak atas Kesehatan. Pemberlakuan UU No. 39 Tahun 1999 tentang Hak Asasi Manusia (HAM) berpedoman pada Deklarasi HAM PBB, Konvensi PBB serta instrumen Internasional lain yang mengatur mengenai HAM.(Penjelasan UU No. 39 Tahun 1999 tentang HAM)

Pemerintah harus dapat memaksimalkan perannya dalam upaya pemberian keadilan terhadap masyarakat. Terlihat kecenderungan Pemerintah untuk lebih memilih tekanan kepentingan Individu/Privat yang berbasis kepentingan bisnis, atau lebih berpihak pada kepentingan yang lebih luas yaitu kepentingan publik, khususnya mengenai kesehatan publik (public health) yang berhubungan dengan obat sebagai salah satu objek Paten baik proses maupun produknya. Disisi lain obat merupakan bagian dari kebutuhan masyarakat luas yang juga merupakan 
kewajiban Pemerintah untuk dapat memenuhi hak atas kesehatan sebagai bagian dari HAM. Hal ini dapat terjawab dengan melakukan analisis mendalam dari beberapa aspek.

Pertama, pengaturan HKI khususnya Paten dalam instrumen hukum Perjanjian Internasional TRIPs. Berdasarkan Pasal 1 ayat (1) tentang Persetujan TRIPs, dinyatakan bahwa:

Members shall give effect to the provisions of this Agreement. Members may, but shall not be obliged to, implement in their law more extensive protection than is required by this Agreement, provided that such protection does not contravene the provisions of this Agreement. Members shall be free to determine the appropriate method of implementing the provisions of this Agreement within their own legal system and practice.

Indonesia yang telah meratifikasi Persetujuan Pembentukan WTO/TRIPs, terikat pada ketentuan tersebut dan memiliki kewajiban untuk menyesuaikan ketentuan perundang-undangan dengan substansi dari Perjanjian Internasional tersebut. Kemudian, wajib menerapkan perlakuan yang ditetapkan dalam persetujuan ini terhadap semua warga anggota lain dalam WTO.

Dalam perjanjian tersebut, perlindungan dan penegakan hukum HKI ditujukan untuk memacu penemuan baru di bidang teknologi dan untuk memperlancar alih serta penyebaran teknologi, dengan tetap memperhatikan kepentingan produsen dan pengguna pengetahuan tentang teknologi dan dilakukan dengan cara yang menunjang kesejahteraan sosial dan ekonomi, dan keseimbangan antara hak dan kewajiban.(Pasal 7 TRIPs). Kemudian, Indonesia harus menyeimbangkan peraturan perundang-undangan nasional sepanjang tidak menyimpang dari ketentuan dalam persetujuan ini, dalam rangka pembentukan dan penyesuaian hukum dan peraturan perundang-undangan nasionalnya, mengambil langkah-langkah yang diperlukan dalam rangka perlindungan kesehatan dan gizi masyarakat, dan dalam rangka menunjang kepentingan masyarakat pada sektor-sektor yang sangat penting bagi pembangunan sosioekonomi dan teknologi.(Pasal 8 ayat (1) TRIPs).

Berdasarkan uraian di atas, maka masalah yang akan dibahas dalam penelitian ini adalah bagaimana bentuk pemberian paten obat-obatan terhadap kesehatan sehingga perlu diberikan pemenuhan hak asasi manusia terhadap pemberian paten obat-obatan atas kesehatan mayarakat di indonesia.

\section{PEMBAHASAN}

\section{a. Pemberian Paten Obat-Obatan terhadap Kesehatan di Indonesia}

Metode pengobatan dan obat-obatan yang tersedia saat ini merupakan hasil daya cipta manusia, yang pada masa awal berkembangnya ilmu pengobatan, diberikan secara cuma-cuma, bahkan disebar luaskan tanpa ada konsekuensi ekonomi atau politis. Filosofis ilmu sendiri mengatakan bahwa mengobati 
seseorang berarti menolong, dan bukan mengambil keuntungan.(Alexandra Indriyanti, 2008: 33).Namun saat ini, setiap penemuan baru baik metode atau obat, selalu disertai lisensi dan hak paten yang kemudian masyarakat yang membutuhkan harus mengeluarkan biaya besar untuk mendapatkannya. Masa lalu suku-suku Indian kuno telah mengerti bahwa akar beberapa tumbuhan sangat efektif untuk dapat mengobati penyakit. Begitupun nenek moyang bangsa Indonesia telah lama mengetahui bahwa didalam akar curcumin ditemukan khasiat penambahan nafsu makan dan mencegah peradangan.

Pada masa itu tidak seorang pun terpikir untuk mematenkan penemuannya, bahkan ada seorang tabib Cina bernama Li Shizen yang hidup pada masa dinasti Ming, telah menghabiskan waktu 40 tahun untuk membuat ensikopedia tanaman obat yang sangat besar manfaatnya itu tanpa memikirkan berapa besar keuntungan yang diperolehnya. Dorongan untuk melakukan penelitian ini lebih disebabkan karena rasa kemanusiaannya yang mendalam ketika mengetahui banyak tabib seringkali salah didalam mencampurkan jenis daun, yang karena nama dan bentuknya hampir sama, membuat pasien bukannya sembuh malah keracunan. Keprihatinan inilah yang kemudian mendorong Li Shizen, untuk mempelajari lebih lanjut berbagai tanaman obat yang berkhasiat tersebut, bahkan menggunakan dirinya sendiri sebagai kelinci percobaan untuk mengetahui reaksi obat tersebut terhadap dirinya, sebelum diberikan kepada pasien. Rasa kemanusiaan yang besar ini seharusnya membuat masyarakat kita yang katanya lebih beradab dan berbudaya malu untuk mempatenkan obat temuannya. Sungguh merupakan kejahatan jika mengambil keuntungan dari penderitaan orang lain. (Alexandra Indriyanti, 2008: 54).

Saat ini dipahami bahwa obat adalah bahan atau paduan bahan, termasuk produk biologi yang digunakan untuk mempengaruhi atau menyelidiki sistem fisiologi atau keadaan patologi dalam rangka penetapan diagnosis, pencegahan, penyembuhan, pemulihan, peningkatan kesehatan dan kontrasepsi, untuk manusia.(Pasal 1 ayat 8 Undang-Undang Nomor 36 Tahun 2009 Tentang Kesehatan). Berdasarkan pengertian tentang obat tersebut, maka dimungkin dalam satu produk obat/ obat jadi terdiri dari beberapa Paten yang melekat. Hal ini sebagaimana dimaksud dalam Undang-Undang Nomor 13 Tahun 2016 tentang Paten (selanjutnya disebut sebagai UU Paten), bahwa pemberian paten dimungkinkan atas suatu invensi dengan suatu langkah yang inventif yang dapat diterapkan dalam Industri, yang memiliki nilai kebaruan (novelty) yang dapat meliputi Produk maupun suatu Proses.Paten adalah hak eksklusif yang diberikan oleh negara kepada inventor atas hasil invensinya di bidang teknologi untuk jangka waktu tertentu melaksanakan sendiri invensi tersebut atau memberikan persetujuan kepada pihak lain untuk melaksanakannya; (Pasal 1 Angka 1 UU Paten). 
UU Paten menguraikan beberapa istilah yang berkaitan dengan pemberian paten. Pengertian Invensi adalah ide inventor yang dituangkan ke dalam suatu kegiatan pemecahan masalah yang spesifik di bidang teknologi berupa produk atau proses, atau penyempurnaan dan pengembangan produk atau proses.(Pasal 1 Angka 2 UU Paten). Inventor adalah seorang atau beberapa orang yang secara bersama-sama melaksanakan ide yang dituangkan ke dalam kegiatan yang menghasilkan Invensi. (Pasal 1 Angka 3 UU Paten). Permohonan adalah permohonan Paten atau Paten sederhana yang diajukan kepada Menteri. (Pasal 1 Angka 4 UU Paten). Pemohon adalah pihak yang mengajukan Permohonan Paten. (Pasal 1 Angka 5 UU Paten). Pemegang Paten adalah Inventor sebagai pemilik Paten, pihak yang menerima hak atas Paten tersebut dari pemilik Paten, atau pihak lain yang menerima lebih lanjut hak atas Paten tersebut yang terdaftar dalam daftar umum Paten. (Pasal 1 Angka 6 UU Paten).

Syarat dan tata cara permohonan terdapat pada Pasal 24 ayat (1) UU Patendiantaranya paten diberikan berdasarkan permohonan; Pasal 24 ayat (2) UU PatenPermohonan sebagaimana dimaksud pada ayat (1) diajukan oleh pemohon atau Kuasanya kepada Menteri secara tertulis dalam bahasa Indonesia dengan membayar biaya; Pasal 24 ayat (3) UU Paten bahwa setiap permohonan diajukan untuk satu Invensi atau beberapa Invensi yang merupakan satu kesatuanInvensi yang saling berkaitan; dan Pasal 24 ayat (4) UU Paten menyatakan permohonan sebagaimana dimaksud pada ayat (2) dapat diajukan baik secara elektronik maupun nonelektronik.

Prosedur permohonan paten terdapat pada Pasal 25 ayat (1) UU Paten yaitu: Permohonan sebagaimana dimaksud dalam Pasal 24, paling sedikit memuat: a. Tanggal, bulan, dan tahun surat Permohonan; b. nama, alamat lengkap, dan kewarganegaraan Inventor; c. nama, alamat lengkap, dan kewarganegaraan Pemohon dalam hal Pemohon adalah bukan badan hukum; d. nama dan alamat lengkap Pemohon dalam hal Pemohon adalah badan hukum; e. nama, dan alamat lengkap Kuasa dalam hal Permohonan diajukan melalui Kuasa; dan f. nama negara dan Tanggal Penerimaan Permohonan yang pertama kali dalam hal Permohonan diajukan dengan Hak Prioritas.

Persyaratan yang harus di penuhi diuraikan pada Pasal 25 ayat (2) UU Paten yaitu: permohonan sebagaimana dimaksud pada ayat (1) harus dilampiri persyaratan: a. judul Invensi; b. deskripsi tentang Invensi; c. klaim atau beberapa klaim Invensi; d. abstrak Invensi; e. gambar yang disebutkan dalam deskripsi yang diperlukan untuk memperjelas Invensi, jika Permohonan dilampiri dengan gambar; f. surat kuasa dalam hal Permohonan diajukan melalui Kuasa; g. surat pernyataan kepemilikan Invensi oleh Inventor; h. surat pengalihan hak kepemilikan Invensi dalam hal Permohonan diajukan oleh Pemohon yang bukan Inventor; dan i. surat bukti penyimpanan jasad renik dalam hal Permohonan terkait dengan jasad renik. Deskripsi. 
Deskripsi paten yang ingin di daftarkan juga diuraikan pada Pasal 25 ayat (3) UU Paten yaitu: Deskripsi tentang Invensi sebagaimana dimaksud pada ayat (2) huruf $\mathrm{b}$ harus mengungkapkan secara jelas dan lengkap tentang bagaimana Invensi tersebut dapat dilaksanakan oleh orang yang ahli di bidangnya. Pasal 25 ayat 4 UU Paten memberikan uraian mengenai klaim atau beberapa klaim Invensi sebagaimana dimaksud pada ayat (2) huruf c harus mengungkapkan secara jelas dan konsisten atas inti Invensi, dan didukung oleh deskripsi sebagaimana dimaksud pada ayat (3).

Berdasarkan databaseDirektorat Jenderal Hak Kekayaan Intelektual (selanjutnya disingkat DJHKI), (Data berdasarkan Database DJHKI sampai dengan bulan Januari 2015) jumlah paten yang berhubungan dengan obat di Indonesia saat ini mencapai 92 (sembilan puluh dua) item yang terdiri dari paten obat, bahan obat dan proses pembuatannya. Berdasarkan data tersebut, ternyata tidak ada satupun Paten yang merupakan milik Indonesia, baik perseorangan, Lembaga Penelitian maupun Perusahaan farmasi. Kemudian, sampai dengan saat ini terdapat 68 (enam puluh delapan) Pendaftaran Paten yang masih dalam di DJHKI yang berhubungan dengan obat-obatan baik metode maupun produk. Kemudian, dari jumlah tersebut hanya 2 (dua) saja yang dimiliki oleh Indonesia.Artinya pemberian Paten atas obat-obatan di Indonesia didominasi oleh Pihak asing, yang mayoritas merupakan negara maju, yaitu Amerika Serikat dengan jumlah yang didaftarkan sebanyak 19 item.

Pengaturan secara norma hukum berdasarkan ketentuan TRIPs Agreement mengenai paten khususnya, yang mana telah diadopsi oleh Indonesia dengan UU Paten, memang diatur secara tegas mengenai ketentuan pemberian paten asing. Konvensi Paris mempunyai prinsip bahwa suatu negara anggota uni memiliki kewajiban untuk memperlakukan orang asing, warga negara dari negara lain anggota uni, sama seperti warga negaranya sendiri dalam masalah paten terlihat dari prioritas penaftaran. Hak Prioritas adalah hak Pemohon untuk mengajukan permohonan yang berasal dari negara yang tergabung dalam Konvensi Paris Tentang Pelindungan Kekayaan Industri (Paris Convention for the Protection of Industrial Property) atau Persetujuan Pembentukan Organisasi Perdagangan Dunia (Agreement Establishing the World Trade Organization) untuk memperoleh pengakuan bahwa Tanggal penerimaan di negara asal merupakan tanggal prioritas di negara tujuan yang juga anggota salah satu dari kedua perjanjian itu selama pengajuan tersebut dilakukan dalam kurun waktu yang telah ditentukan berdasarkan perjanjian internasional dimaksud. (Pasal 1 angka 12 UU Paten). Penemu asing dengan sendirinya telah meminta paten di negaranya sendiri, tetapi agar penemuannya dilindungi di negara lain, ia harus pula memintakan perlindungan tersebut di negara lainnya.

Perlindungan paten asing tersebut, mengenai obat-obatan khususnya, sama dengan perlindungan paten Indonesia lainnya. 
Hanya yang membedakan adalah paten asing disuatu negara harus menggunakan hak prioritas sebagaimana diatur dalam pasal 27 dan 28 UU Paten, yang kemudian dalam 29 dinyatakan bahwa ketentuan lebih lanjut mengenai permohonan bukti Hak Prioritas dari Direktorat Jenderal dan Permohonan yang diajukan dengan Hak Prioritas diatur dengan Keputusan Presiden. Perlindungan hukum yang terhadap paten asing yang didaftarkan di Indonesia, yaitu apabila terjadi peniruan teknologi terhadap paten asing yang sudah didaftarkan, dapat diajukan gugatan pembatalan paten. Hal ini merupakan salah satu alasan bahwa bisnis farmasi di Indonesia sangat menggiurkan.

Dari sisi hak paten, pendaftaran hak paten farmasi di Indonesia masih minim. Padahal dengan perlindungan hak paten farmasi, industri farmasi bisa lebih berkembang. Dengan hak paten, produsen farmasi tidak ragu lagi untuk mengambangkan produknya di pasaran. Produsen farmasi juga bisa mengeruk keuntungan dengan memberikan lisensi patennya pada pihak lain. Penerima lisensi juga terlindungi karena produk berlisensi sudah terlindungi paten. Pada sisi lain, perlindungan paten berdampak pada akses masyarakat terhadap obat. dampak perlindungan paten itu adalah tertundanya ketersediaan obat inovasi esensial yang dibutuhkan masyarakat dan umumnya masih dalam perlindungan paten.

Harus diakui bahwa pemberlakuan perundang-undangan HKI pada era 80an berhasil mengundang masuknya modal asing berikut teknologi yang menyertainya. Namun disayangkan bahwa masuknya modal asing dan teknologi ke Indonesia itu tidak diikuti dengan tingkat kemandirian ekonomi. Artinya secara ekonomi, Indonesia masih tetap berada di bawah dominasi negara-negara maju, (Agus Sardjono, 2009:19), termasuk dalam bidang farmasi khususnya obat-obatan.

Syarat dan tata cara permohonan paten terdapat pada Pasal 24 ayat (1) UU Patendiantaranya diberikan berdasarkan permohonan. Prosedur dan deskripsi dari paten yang didaftarkan juga diatur sebagai pemenuhan hak prioritas bagi yang lebih dulu bagi inventor yang mendaftarkan invensinya. Hak prioritas juga berlaku bagi warga negara asing yang tergabung dalam Konvensi Paris diatur pada Pasal 1 angka 12 UU Paten. Tujuan ideal dari pembentukan dan pemberian paten obat-obatan di Indonesia ternyata tidak demikian mudah untuk diwujudkan. Kenyataan dalam implementasi hukumnya terbukti tidak sejalan dengan dengan gagasan awalnya bahwa pembentukan hukum kekayaan intelektual diharapkan dapat meningkatkan pertumbuhan ekonomi dan meningkatkan kesejahteraan Indonesia.

\section{b. Pemenuhan Hak Asasi Manusia terhadapPemberian Paten Obat- Obatan atas Kesehatan Mayarakat di Indonesia}

Jumlah paten yang terdaftar di DJHKI yang berhubungan dengan obat, baik proses maupun produk, sampai dengan saat ini didominasi oleh pihak asing. 
Tentunya hal ini berdampak pada harga obat yang tidak terjangkau oleh masyarakat miskin di Indonesia. Kondisi tersebut bisa membuat hak masyarakat terhadap akses pengobatan jadi terhambat karena tidak semua warga memiliki asuransi kesehatan. Adanya perjanjian Perdagangan terkait Hak Kekayaan Intelektual yaitu TRIPs Agreement, turut menghambat persaingan industri obat. Sebab, dalam perjanjian itu diberlakukan paten terhadap produk obat dari industri farmasi sehingga perusahaan farmasi yang memegang hak paten bisa memonopoli suatu obat.

Jangkauan daya beli masyarakat terhadap harga obat yang mahal akibat adanya monopoli berupa pemberian paten tentunya sangat lemah. Masyarakat yang mampu pun, jika kemudian ia sakit dan membutuhkan obat yang telah dilindungi oleh paten dengan jumlah yang banyak dan kontinyu, maka pada akhirnya pun akan memiskinkan dirinya. Penyalahgunaan paten obat maupun lisensinya, yang kemudian menimbulkan monopoli atau persaingan usaha tidak sehat, tidaklah merupakan suatu pelanggaran. Padahal jika dicermati bahwa pemberian hak eksklusif atas obat dapat menimbulkan dominasi dan jika disalahgunakan dapat menimbulkan monopoli dan persiangan usaha tidak sehat.

Terbukti bahwa dalam hal ini berdampak pada harga obat menjadi mahal dan tidak terjangkau. Mengutip pernyataan Judit Rius (Medecins Sans Frontieres), bahwa harga obat bisa mahal karena kurangnya persaingan antar industri farmasi. Makin banyak kompetitor, harga obat menjadi murah. Perjanjian Perdagangan terkait Hak Kekayaan Intelektual (Trade Related Aspects of Intellectual Property Rights/TRIPs) turut menghambat persaingan industri obat. Sebab, dalam perjanjian itu diberlakukan paten terhadap produk obat dari industri farmasi sehingga perusahaan farmasi yang memegang hak paten bisa memonopoli suatu obat.(http://health.kompas.com/read/2014/11/14/071000223/Ini.Penyebab.Har ga.Obat.Mahal, diakses pada 16 Januari 2015).

Harga obat yang mahal berpengaruh terhadap upaya mewujudkan, mempertahankan dan meningkatkan derajat kesehatan masyarakat yang setinggitingginya. Kesehatan merupakan hak asasi manusia dan salah satu kesejahteraan yang harus diwujudkan sesuai dengan cita-cita bangsa Indonesia sebagaimana dimaksud dalam Pancasila dan Undang-Undang Dasar 1945. (Konsideran menimbang huruf (a) UU Nomor 36 Tahun 2009 tentang Kesehatan). Tidak terpenuhinya dan terjangkaunya akses terhadap obat-obatan bagi masyarakat, maka akan menghambat upaya pemenuhan HAM atas Kesehatan di Indonesia. Hal ini merupakan tanggung jawab Negara untuk mengatasi permasalahan mengenai harga obat yang mahal dan memastikan akses terhadap sedian farmasi terhadap seluruh masyarakat.

Perkembangan pemikiran HAM menunjukkan adanya kesinambungan gagasan terhadap pentingnya perlindungan dan pemenuhan HAM. Setidaknya dikenal tiga bahkan empat generasi HAM. 
Elemen dasar dari konsepsi generasi HAM pertama mencakup soal prinsip integritas manusia, kebutuhan dasar manusia dan kebebasan sipil dan politik. (Jimly Asshiddiqie, 2005: 221).

Perkembangan pemikiran HAM juga mengalami peningkatan ke arah kesatupaduan antara hak-hak ekonomi, sosial, budaya, politik dan hukum dalam "satu keranjang" yang disebut dengan hak untuk pembangunan (the right to development). Inilah generasi HAM ketiga. Hak untuk pembangunan mencakup persamaan hak atau kesempatan untuk maju yang berlaku bagi segala bangsa, dan termasuk hak setiap orang yang hidup sebagai bagian dari kehidupan bangsa tersebut. Hak ini meliputi hak untuk berpartisipasi dalam proses pembangunan sekaligus menikmati hasil-hasil pembangunan tersebut. (Jimly Asshiddiqie, 2005: 222).Keterlibatan pihak swasta sebagai Produsen Obat di Indonesia, seharusnya korporasi itu harus menghormati HAM yang diakui secara Internasional, bahkan apabila HAM ini tidak diakui di dalam sistem hukum nasional.

Pemerintah bertanggungjawab merencanakan, mengatur, menyelenggarakan, membina, dan mengawasi penyelenggaraan upaya kesehatan yang merata dan terjangkau oleh masyarakat (Pasal 11 ayat (1) UU Kesehatan), termasuk dalam upaya menyediakan fasilitas obat-obatan yang bermutu, aman, efisien, dan terjangkau sebagaimana dimaksud dalam Pasal 36 ayat (1) UU Kesehatan.

Medio Februari Tahun 2015, (http://lipsus.kompas.com/topikpilihanlist /3446/1/Kasus.Anestesi.di.RS.Siloam, diakses pada 24 Februari 2015) terdapat kasus dugaan tertukarnya isi obat anestesi Buvanest Spinal dengan asam traneksamat produksi PT. Kalbe Farma,yang mengakibatkan meninggalnya dua orang pasien yang dioperasi di Rumah Sakit Siloam, Karawaci. Perusahan yang memproduksi obat tersebut merupakan perusahaan swasta.

Kejadian tersebut, dalam perspektif HAM merupakan pelanggaran Negara terhadap kewajiban mereka berdasarkan hukum hak asasi manusia Internasional dan Nasional,(Kovenan Hak EKOSOB yang telah di Ratifikasi oleh Indonesia, dalam pasal 12 ayat (1)) dimana pelanggaran tersebut dapat dipertanggung jawabkan ke mereka atau dimana mereka gagal untuk melakukan langkah-langkah yang cukup untuk mencegah, menyelidiki, menghukum dan memulihkan terhadap pelanggaran oleh aktor swasta.

Maka seharusnya negara melindungi dan memajukan supremasi hukum (rule of law), termasuk dengan melakukan penjaminan kesamaan di hadapan hukum, keadilan dalam penerapannya, dan dengan menyediakan pertanggungjawaban yang cukup, kepastian hukum, dan prosedur dan transparansi hukum. Mengenai ketersediaan segala bentuk upaya kesehatan yang bermutu, aman, efisien, dan terjangkau, dalam UU Kesehatan dinyatakan secara tegas merupakan tanggung jawab Pemerintah.( Pasal 19 UU Kesehatan). 
Pemberian sanksi oleh pemerintah kepada Pihak Swasta mengenai kegiatan memproduksi atau mengedarkan sediaan farmasi dan/atau alat kesehatan yang tidak memenuhi standar dan/atau persyaratan keamanan, khasiat atau kemanfaatan, dan mutu, dalam Pasal 196 UU Kesehatan dinyatakan:

Setiap orang yang dengan sengaja memproduksi atau mengedarkan sediaan farmasi dan/atau alat kesehatan yang tidak memenuhi standar dan/atau persyaratan keamanan, khasiat atau kemanfaatan, dan mutu sebagaimana dimaksud dalam Pasal 98 ayat (2) dan ayat (3) dipidana dengan pidana penjara paling lama 10 (sepuluh) tahun dan denda paling banyak Rp1.000.000.000,00 (satu miliar rupiah)

Apabila kegiatan tersebut dilakukan oleh korporasi maka selain pidana penjara dan denda terhadap pengurusnya, pidana yang dapat dijatuhkan terhadap korporasi berupa pidana denda dengan pemberatan 3 (tiga) kali dari pidana denda.(Pasal 201 ayat (1) UU Kesehatan). Selain pidana penjara dan denda, korporasi dapat dijatuhi pidana tambahan berupa pencabutan izin usaha dan/atau pencabutan status badan hukum.

Korporasi dilain sisi juga harus menghormati HAM yang diakui secara Internasional, bahkan apabila HAM ini tidak diakui di dalam sistem hukum nasional. Selain itu, ketika konflik hukum nasional dengan hukum internasional, korporasi harus berusaha untuk menghormati prinsip-prinsip dan standar HAM Internasional, sekaligus mematuhi hukum domestik. Sehingga, korporasi dapat mengatasi risiko berkontribusi dalam terjadinya pelanggaran HAM.

Dalam penjelasan umum Undang-Undang No. 39 Tahun 1999 tentang Hak Asasi Manusia, antara lain menyebutkan bahwa undang-undang ini secara rinci mengatur mengenai hak-hak, seperti hak memperroleh keadilan, hak atas rasa aman, hak atas kesejahteraan. Hak-hak ini dilindungi oleh negara/pemerintah melalui aparat penegak hukum, sebagai perlindungan terhadap orang/kelompok/korporasi dari kejahatan yang dilakukan oleh orang/kelompok/korporasi lainnya.

Perlindungan hak-hak yang berkaitan erat dengan HAM harus ditanggulangi oleh negara/pemerintah, dengan pembentukan hukum yang dapat diterapkan dalam praktik pelaksanaan proses peradilan oleh aparat penegak hukum. Kemudian, kebijakan atau upaya untuk meningkatkan kesejahteraan warganya, khususnya dalam bidang Kesehatan berupa sediaan Farmasi, merupakan bagian integral dari upaya perlindungan masyarakat (social defence) dan upaya mencapai kesejahteraan masyarakat, yang tujuan utamanya adalah perlindungan masyarakat untuk mencapai kesejahteraan masyarakat. (Frans Magnis Suseno, 1999: 121122).

Konsep negara hukum dan kesejahteraan, bahwa negara mempunyai kewajiban menjamin terciptanya kesejahteraan bersama dalam kehidupan bermasyarakat, baik yang menyangkut kepentingan ekonomi, sosial, budaya, 
hukum, pendidikan, maupun dalam kepentingan politik.(Luthfi J. Kurniawan dan Mustafa Luthfi, 2012: 49). Hal ini tentu saja sejalan dengan Pembukaan UUD 1945 khususnya alinea IV yang menyebutkan: “...kemudian dari pada itu untuk membentuk suatu pemerintahan negara Indonesia yang melindungi segenap bangsa indonesia dan seluruh tumpah darah indonesia dan untuk memajukan kesejahteraan umum....". Dari Landasan tersebut menegaskan adanya kewajiban negara dan tugas pemerintah untuk melindungi dan melayani sehenap kepentingan publik, guna mewujudkan kebahagiaan seluruh rakyat Indonesia.

Kemudian dalam UUD 1945, Indonesia menegaskan bahwa negara Indonesia adalah negara hukum. Lunshof (1989) mengemukakan (Dalam : Agussalim Andi Gajong, 2007: 31) bahwa unsur negara hukum adalah :

a) Adanya pemisahan antara pembentuk undang-undang, pelaksana undangundang, dan peradilan;

b) Bahwa penyusun undang-undang secara demokratis;

c) Adanya asas legalitas;

d) Adanya pengakuan terhadap hak asasi manusia (HAM).

Dengan demikian maka Indonesia sebagai negara hukum harus memberikan perlindungan, pemenuhan dan penghormatan HAM bagi rakyatnya. HAM adalah sesuatu yang melekat pada diri seseorang sebagai ciptaan Tuhan agar mampu menjaga harkat, martabatnya dan keharmonisan lingkungan. Hak asasi merupakan hak dasar yang melekat secara kodrati pada diri manusia dengan sifatnya yang universal dan abadi. Oleh karena itu harus dilindungi, dihormati, dipertahankan, tidak boleh diabaikan, tidak boleh dikurangi dan dirampas oleh siapapun. HAM perlu mendapat jaminan atas perlindungannya oleh negara melalui pernyataan tertulis yang harus dimuat dalam Konstitusi.

Karena HAM merupakan hak yang diperoleh saat kelahirannya sebagai manusia, maka HAM meliputi hak-hak yang apabila dicabut atau dikurangai akan mengakibatkan berkurang derajat kemanusiaannya. Ukuran derajat kemanusiaan selalu berkembang sesuai dengan peradaban masyarakatnya. Jelas bahwa hak dasar pertama adalah hak hidup yang membawa konsekuensi adanya hak-hak lain seperi hak mendapatkan kehidupan dan pekerjaan yang layak, hak berkeluarga dan melanjutkan keturunan, hak mendapatkan kewarganegaraan dan hak mengeluarkan pendapat, berserikat dan berkumpul. Pada perkembangan selanjutnya, derajat kemanusiaan juga ditentukan oleh tingkat pendidikan dan kesehatannya, sehingga pendidikan dan kesehatan pun kemudian menjadi hak asasi manusia dengan segala perangkat hak lain untuk mendapatkan pendidikan dan kesehatan.

Pelaksanaan ketentuan mengenai hak kesehatan merupakan hak konstitusional yang diberikan negara kepada rakyat ini, dalam prakteknya dipertegas melalui Undang-undang dan Peraturan pelaksanaan lainnya sesuai dengan hirarki perundang-undangan. 
Undang-undang No. 36 Tahun 2009 tentang Kesehatan (UU Kesehatan), menjamin bahwa kesehatan adalah hak semua orang, dan setiap orang mempunyai hak yang sama dalam memperoleh akses atas sumber daya di bidang kesehatan. Sumber daya di bidang kesehatan adalah segala bentuk dana, tenaga, perbekalan kesehatan, sediaan farmasi dan alat kesehatan serta fasilitas pelayanan kesehatan dan teknologi yang dimanfaatkan untuk menyelenggarakan upaya kesehatan yang dilakukan oleh Pemerintah, pemerintah daerah, dan/atau masyarakat.

Sediaan farmasi merupakan Sediaan farmasi adalah obat, bahan obat, obat tradisional, dan kosmetika.(Pasal 1 ayat (4) UU Kesehatan jo. Pasal 1 ayat (1) PP Nomor 72 Tahun 1998 tentang Pengamanan Sediaan Farmasi dan Alat Kesehatan). Hak atas kesehatan beserta akses terhadap sumber daya dalam bidang kesehatan merupakan satu kesatuan hak untuk memperoleh derajat kesehatan tertinggi yang dimaksudkan dalam pengakuan HAM. Pemerintah bertanggung jawab atas ketersediaan sumber daya di bidang kesehatan yang adil dan merata bagi seluruh masyarakat untuk memperoleh derajat kesehatan yang setinggi-tingginya.(Pasal 16 UU Kesehatan). Kaitannya dengan pemenuhan hak kesehatan yang berhubungan dengan pemberian paten terhadap obat-obatan, yang dampaknya telah diuraikan sebelumnya, khususnya mengenai harga dan akses terhadap obat, Pemerintah bertanggung jawab atas ketersediaan segala bentuk upaya kesehatan yang bermutu, aman, efisien, dan terjangkau.(Pasal 19 UU Kesehatan).

Selanjutnya, Pemerintah memiliki kewajiban untuk menjamin ketersediaan, pemerataan, dan keterjangkauan perbekalan kesehatan, terutama obat esensial. Dalam menjamin ketersediaan obat keadaan darurat, Pemerintah dapat melakukan kebijakan khusus untuk pengadaan dan pemanfaatan obat dan bahan yang berkhasiat obat.(Pasal 36 ayat (1) dan (2) UU Kesehatan).Pengelolaan perbekalan kesehatan yang berupa obat esensial dan alat kesehatan dasar tertentu dilaksanakan dengan memperhatikan kemanfaatan, harga, dan faktor yang berkaitan dengan pemerataan.

Hak asasi manusia atas kesehatan diakui dalam perangkat-perangkat internasional. Deklarasi Universal Hak Asasi Manusia menyatakan:

"Setiap manusia mempunyai hak atas standar kehidupan yang cukup, bagi kesehatan dirinya sendiri dan keluarganya, yang mencakup makanan, tempat tinggal, pakaian dan pelayanan kesehatan serta pelayanan sosial yang penting".(Pasal 25 ayat (1) Deklarasi Universal Hak-Hak Asasi Manusia, 1948)

Jaminan hak atas kesehatan juga terdapat dalam Pasal 12 ayat (1) Konvensi Internasional tentang Hak Ekonomi, Sosial dan Budaya yang ditetapkan oleh Majelis Umum Perserikatan Bangsa-Bangsa (PBB) 2200 A (XXI) tanggal 16 Desember 1966, yaitu bahwa negara peserta konvenan tersebut mengakui hak setiap orang untuk menikmati standar tertinggi yang dapat dicapai dalam hal kesehatan fisik dan mental. 
Indonesia telah meratifikasi beberapa Konvenan Internasional yang mengatur mengenai HAM, termasuk di dalamnya Hak atas Kesehatan. Pemberlakuan UU No. 39 Tahun 1999 tentang Hak Asasi Manusia (HAM) berpedoman pada Deklarasi HAM PBB, Konvensi PBB serta instrumen Internasional lain yang mengatur mengenai HAM.(Penjelasan UU No. 39 Tahun 1999 tentang HAM).

Pemerintah harus dapat memaksimalkan perannya dalam upaya pemberian keadilan terhadap masyarakat. Terlihat kecenderungan Pemerintah untuk lebih memilih tekanan kepentingan Individu/Privat yang berbasis kepentingan bisnis, atau lebih berpihak pada kepentingan yang lebih luas yaitu kepentingan publik, khususnya mengenai kesehatan publik (public health) yang berhubungan dengan obat sebagai salah satu objek Paten baik proses maupun produknya. Disisi lain obat merupakan bagian dari kebutuhan masyarakat luas yang juga merupakan kewajiban Pemerintah untuk dapat memenuhi hak atas kesehatan sebagai bagian dari HAM.

\section{PENUTUP}

Syarat dan tata cara permohonan paten terdapat pada Pasal 24 ayat (1) UU Patendiantaranya diberikan berdasarkan permohonan. Prosedur dan deskripsi dari paten yang didaftarkan juga diatur sebagai pemenuhan hak prioritas bagi yang lebih dulu bagi inventor yang mendaftarkan invensinya. Hak prioritas juga berlaku bagi warga negara asing yang tergabung dalam Konvensi Paris diatur pada Pasal 1 angka 12 UU Paten. Tujuan ideal dari pembentukan dan pemberian paten obat-obatan di Indonesia ternyata tidak demikian mudah untuk diwujudkan. Kenyataan dalam implementasi hukumnya terbukti tidak sejalan dengan dengan gagasan awalnya bahwa pembentukan hukum kekayaan intelektual diharapkan dapat meningkatkan pertumbuhan ekonomi dan meningkatkan kesejahteraan Indonesia.

Pemerintah memiliki kewajiban untuk menjamin ketersediaan, pemerataan, dan keterjangkauan perbekalan kesehatan, terutama obat esensial. Dalam menjamin ketersediaan obat keadaan darurat, Pemerintah dapat melakukan kebijakan khusus untuk pengadaan dan pemanfaatan obat dan bahan yang berkhasiat obat. (Pasal 36 ayat (1) dan (2) UU Kesehatan). Terlihat kecenderungan Pemerintah untuk lebih memilih tekanan kepentingan individu/privat yang berbasis kepentingan bisnis, atau lebih berpihak pada kepentingan yang lebih luas yaitu kepentingan publik, khususnya mengenai kesehatan publik (public health) yang berhubungan dengan obat sebagai salah satu objek paten baik proses maupun produknya. Disisi lain obat merupakan bagian dari kebutuhan masyarakat luas yang juga merupakan kewajiban Pemerintah untuk dapat memenuhi hak atas kesehatan sebagai bagian dari HAM. Pemerintah harus dapat memaksimalkan perannya dalam upaya pemberian keadilan terhadap masyarakat. 


\section{DAFTAR PUSTAKA}

\section{A. Buku}

Agus Sardjono, Membumikan HKI di Indonesia, (Bandunng: Nuansa Aulia, 2009)

Alexandra Indriyanti Dewi, Mafia Kesehatan, (Yogyakarta, Penerbit Pinus Book Publisher, 2008).

Bahder Johan Nasution, Negara Hukum dan Hak Asasi Manusia, Bandung: Penerbit Mandar Maju, 2011).

Candra Irawan, Politik Hukum Hak Kekayaan Intelektual Indonesia: Kritik Terhadap WTO/TRIPs Agreement dan Upaya Membangun Hukum Kekayaan Intelektual Demi Kepentingan Nasional, (Bandung: Penerbit CV. Mandar Maju, 2011),

Frans Magnis Suseno, Etika Politik, (Jakarta: Gramedia Pustaka Utama, 1999)

Jimly Asshiddiqie, Hukum Tata Negara dan Pilar-pilar Demokrasi (Jakarta: Konstitusi Press, 2005)

Luthfi J. Kurniawan dan Mustafa Luthfi, Perihal Negara, Hukum dan Kebijakan Publik : Perspektif Politik Kesejahteraan yang Berbasis Kearifan Lokal, Pro Civil Society dan Gender, (Malang, Setara Press, 2012),

Muhamad Djumhana dan R. Djubaedillah, Hak Milik Intelektual : Sejarah, Teori dan Praktiknya di Indonesia, (Bandung: Penerbit PT. Citra Adiyta Bhakti, 2014)

Wahyu Sasongko, Indikasi Geografis : Studi Tentang Kesiapan Indonesia memberikan perlindungan hukum terhadap produk nasional, (Bandar Lampung: Penerbit Universitas Lampung, 2012)

\section{B. Peraturan Perundang-undangan}

Deklarasi Universal Hak-Hak Asasi Manusia, 1948.

TRIPs Agreement.

UU No. 13 Tahun 2016 tentang Paten.

UU No. 39 Tahun 1999 tentang HAM.

UU No. 36 Tahun 2009 tentang Kesehatan.

\section{Sumber Lain}

http://en.wikipedia.org/wiki/Beecham Group

http://www.hakpaten.net/hak-paten-pengertian-hak-paten/

http://id.wikipedia.org/wiki/Hak,

http://health.kompas.com/read/2014/11/14/071000223/Ini.Penyebab.Harga.Ob

at.Mahal,

http://lipsus.kompas.com/topikpilihanlist/3446/1/Kasus.Anestesi.di.RS.Siloam 


\section{PEDOMAN PENULISAN JURNAL PRANATA HUKUM}

1. Naskah bersifat orisinil, baik berupa hasil riset atau tinjauan atas suatu permasalahan hukum yang berkembang di masyarakat (artikel lepas), dimungkinkan juga tulisan lain yang dipandang memberikan kontribusi bagi pengembangan ilmu hukum.

2. Penulisan terdiri atas beberapa bab penulisan hasil penelitian terdiri dari 3BAB,yaitu ;

BAB I. PENDAHULUAN (Latar Belakang dan Rumusan Masalah) BAB II. PEMBAHASAN (Kerangka Teori dan Analisis), dan BAB III. PENUTUP (Kesimpulan dan Saran).

3. Tulisan menggunakan bahasa indonesia maupun bahasa inggris yang memenuhi kaidah bahasa yang baik dan benar,tulisan menggunakan bahasa indonesia disertai abstrak dalam bahasa inggris (200 kata) dan Kata kunci, ketentuan ini berlaku sebaliknya.

4. Setiap kutipan harus menyebutkan sumbernya, dan ditulis pada akhir kutipan dengan memberi tanda kurung (bodynote). Sumber kutipan harus memuat nama pengaran, tahun penerbitan dan halaman .Contoh : satu penulis (Bagir Manan, 1994: 20), Dua Penulis (Jimly Asshidiqqie dan M.Ali Syafa'at, 2005: 11), Tiga atau lebih penulis menggunakan ketentuan et.al (dkk). Untuk artikel dari internet dengan susunan: nama penulis, judul tulisan digaris bawah, alamat website, waktu download/unduh.

5. Naskah harus disertai dengan daftar pustaka atau referensi ,terutama yang digunakan sebagai bahan acuan langsung. Daftar pustaka dan referensi bersifat alfabetis dengan format; nama pengarang, judul buku, nama penerbit, kota terbit, dan tahun penerbitan. Contoh: Bagir Manan, Hubungan Antara Pemerintah Pusat dan Daerah Menurut UUD 1945, Pustaka Sinar Harapan, Jakarta, 1994.

6. Panjang tulisan antara 15-25 halaman, font times new roman dengan 1,15 spasi. Dalam hal hal tertentu berlaku pengecualian panjang tulisan.

7. Naskah disertai nama lengkap penulis, alamat e-mail dan lembaga tempat berafiliasi saat ini, dan hal lain yang dianggap penting. 


\section{Jurnal PRANATA HUKUM dimaksudkan sebagai}

media komunikasi, edukasi, dan informasi ilmiah bidang ilmu hukum khususnya, dan ilmu sosial pada umumnya. Sajian dan kemasan diupayakan komunikatif melalui bahasa ilmiah.

Redaksi mengundang semua elemen masyarakat baik civitas akademika, praktisi, lembaga masyarakat, maupun perorangan yang berminat terhadap bidang hukum untuk berpartisipasi mengembangkan gagasan, wawasan, dan pengetahuan melalui tulisan untuk dimuat dalam jurnal ini.

Melalui PRANATA HUKUM diharapkan terjadi proses pembangunan dan pengembangan bidang hukum sebagai bagian penting dari rangkaian panjang proses memajukan masyarakat bangsa.

Alamat Redaksi

PRANATA HUKUM

Kampus B Universitas Bandar Lampung Jl. ZA Pagar Alam No.89 Labuhan Ratu, Bandar

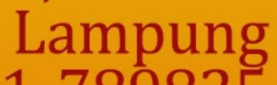

Telp: 0721-789825

Email: jurnal.mh@ubl.ac.id

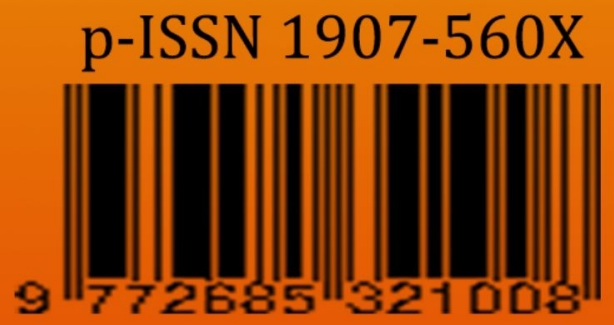

